\title{
'Dailiness' in the New Media Environment: Youth Media Practices and the Temporal Structure of Life-World
}

\author{
Antonija Čuvalo*
}

\section{SUMMARY}

The paper explores the way young people use available multimedia environments in the context of everyday life. The focus is on time and everyday temporalities (re)produced through the day-to-day interaction with the diverse media and communication technologies. Paper draws on the concept of "dailiness" (Scannell, 1996) which is broadened and applied to the multimedia environment by combining the phenomenological approach with the conceptualization of time within the domestication theory (Silverstone, 1993a, 1994).Findings are based on the qualitative interpretative analysis of communication diaries and autobiographical reflections on media use. Six temporal genres are identified: slowing down, flow management, time machine, orientation toward public flows, going with the flow, orientation toward personalized flows. The identified genres also describe how the dominant temporal orientation of contemporary late modern societies is negotiated, resisted, confirmed and managed in actual dayto-day contacts with the media.

Key words: new media environment, temporal genres of media use, social practice, life-world, mediatized societies

\footnotetext{
*Antonija Čuvalo, PhD, postdoctoral fellow, Centre for Media and Communication Research, Faculty of Political Science, University in Zagreb / Centar za istraživanje medija i komunikacije, Fakultet političkih znanosti, Sveučilište u Zagrebu, Lepušićeva 6, 10000 Zagreb, antonija.cuvalo@fpzg.hr
} 
Medij. istraž. (god. 22, br. 1) 2016. (65-86)

\section{Introduction}

This paper aims to contribute to the understanding of the experience of time in relation to media use as part of day-to-day activities of media-savvy youth in late modern, mediatized or "media-saturated" societies (Lundby, 2009). Information and communication media are seen as the technologies that structure and mould everyday temporalities toward the "present" orientation which is "underwritten by the institutions of power and economy" (Silverstone, 1993: 291), and "is woven into the fabric of our ordinary days" (Morley, 2003: 108). The main assumption here is that our practical involvement with the material world, including communication technologies, "is temporal to its core", while the patterns of time and the temporalities of everyday life in late modern "mediatized societies" cannot be adequately addressed "without the use of technology, which permeates our everyday life" (Hörning et al., 1999:294). There is an intensive theoretical debate within social theory (Crary, 2013; Tomlinson, 2007, Virilio, 2005 Castells, 2000; Harvey, 1989, Giddens, 1991) and media studies (see, among others, Moores 2005, 2006; Morley, 2003; Meyerowitz, 1985, Silverstone, 1993a, 1994) concerning how notions of time and space are changing in late modern societies and how new technologies, especially media and communication technologies, contribute to changes of time and space. Nevertheless, there is still a big lacuna to fill if we want to understand everyday experiences of time in the context of daily life in a multimedia environment. Only a few empirical studies deal with the temporalities produced through individual contact with information and communication media within the context of everyday life (Green, 2002; Nansen et al., 2009, Hörning et al., 1999).

The paper aims to find out what types of temporalities (temporal genres of media use) these negotiations produce in the context of everyday life of young generations, and how different media have been used as temporal resources within these genres. Differences between them point to the different types of mediatized habitus which shows a tendency toward specific temporal practices. Young people are hereby taken as the socially embedded actors with a particular type of mediatized habitus (Hjarvard, 2013) developed through the interaction with affordances of the multimedia environment from their early childhood. Their individual media practices and temporal orientations are developed through negotiations between moral economy of their families (Silverstone, 1993a) and the pressures of wider mediatized society, which are manifested as the dominance of "spaces of flows" (Castells, 2000), or as the dominant temporal orientation toward the present (Silverstone, 1993, 1994).The findings are based on the qualitative interpretative analysis of the communication diaries and autobiographical reflections on media use written by 64 students $(5$ male, 59 female) of the first year of the graduate study of journalism at the Faculty of Political Science in Zagreb (intensity sample). The sample consists of young 
adults (23 - 26 years old) who consider themselves „,media-savvy” users with developed media competences and skills. They were born between 1985 and 1988, and are usually placed within the so-called "millennial generation" or "digital natives" (Prensky, 2001). They are considered the first generation born into the digital environment whose lives are profoundly affected by information and communication technologies. To examine how everyday media use in the new media environment (Livingstone \& Bovill, 1999; Meyerowitz, 1985) is integrated in the experience of time, a theoretical framework is applied which combines the conceptualization of media use as social practice (Couldry, 2012, 2010; see also Brauchler \& Postill, 2010; Reckwitz, 2002; Schatzki 1996), media phenomenology and phenomenological approach to time (Scannell, 1996; see also Schutz \& Luckmann, 1973), and the domestication theory (Silverstone, 1993a, 1994).In the next section I suggest a broader concept of 'dailiness', which draws on the critique of the phenomenological perspective (Moores, 2005; Morley, 2003) and takes into account structural (vertical) aspects together with the (horizontal) everyday contacts with the media. This concept will provide the basis for developing the typology of temporal genres of media use, where different genres describe complexities of temporalities (re) produced through everyday contacts with media. After a brief description of the research method, I will present the results by analysing identified genres of media use and by portraying everyday temporal experiences of different types of mediatized habitus.

\section{Dailiness' and Multimedia Environments}

Within media studies, the role of communication media in the temporal structuring of everyday life is analysed from the phenomenological perspective (Scannell, 1996), through the concept of 'dailiness', which has been applied to the broadcast media of radio and television. "Dailiness" refers to the role of broadcast media in "the fundamental temporal structuring of everyday life" (Silverstone, 1993: 294; see also in Scannell, 1996), which is based on the recursiveness and repetitive nature of everyday life. British media scholar Roger Silverstone (1993a, 1994) introduced concepts of (underlying) temporal 'orientation' and 'clocking' as practical temporal engagement, in order to analyse the temporal dimension of the domestication of information and communication technologies in households. Silverstone (1993a, 1994) analysed how the dominant social orientation toward the constantly changing spaces of flows, inscribed into the communication media and technologies, is negotiated in the daily life of the household. In the paper, I draw on the concepts of orientation and clocking as the threshold for the analysis of different genres of media use. These genres represent at the same time complexities of 'dailiness' in contemporary late modern societies and the typical ways in which young 
people deal with the dominant social orientation within the context of their everyday life.

In order to overcome the weaknesses of the phenomenological view on the role of media in the (re) production of 'dailiness' (Morley, 2003; Moores, 2005), a broader concept of 'dailiness' is suggested here which takes into account both the structural and the vertical dimension of media use and everyday contacts with media. This is based on three basic meta-theoretical assumptions. First, contemporary media environments provide "ensembles of combined affordances" (Lepa et al., 2014: 209) through their dominant temporal orientation toward the present. Second, young "media-savvy users" are seen as socially, culturally and politically situated social actors. The third assumption points to the interdependence of time, space, and social relations (Silverstone, 1993a).

The first assumption relies on the notion of "affordances" from the work of American ecological psychologist James J. Gibson (1986/1979). Different specific media technologies provide specific affordances or "an abstract ideal-typical space of possibilities to perceive and act on the environment" (Lepa et al., 2014: 209). According to Lepa and colleagues (2014: 209) "affordances" refers to "a real material potential in each media technology 'waiting' to be perceived, interpreted, and actualized before it can become a part of empirically observable praxis". Contemporary complex media environments offer "ensembles of combined affordances" (Lepa et al., 2014: 209) which also involve the capacity of media technologies to structure everyday temporalities. 'Dailiness' is thus (re) produced through the actualization of the combined "affordances" of the complex media environments.

The second assumption refers to the socially, culturally, economically and politically situated nature of media use (Baker et al., 2006; Haddon, 2007; Silverstone et al., 1992). According to the domestication theory (Silverstone 1994, 1993a, see also Silverstone et al., 1992), the patterns of media use are seen as "dependent on, and as expression of" the particular 'moral economy' of the household or family which serves as the viable social, cultural, and economical unit for media adoption and use(Silverstone, 1993a). Characteristics of the moral economy of the particular household or family involve their own rationalities, allowing them to operate according to their own moral and economic values, "which needs to be understood both in its own terms and in relation to the wider politics and economics of the public sphere" (Silverstone, 1993a: 286). Unlike the domestication theory, the focus here is not on the households, but on the individual adoption and use of media. Individuals are conceptualized as social actors who are members of different social figurations (Elias, 2007) and life-worlds (Hepp, 2013) like family, friends, students of journalism and public relations etc., which are themselves complex social, cultural and political environments (Silverstone, 1993a). Actors from different social 
'Dailiness' in the New Media Environment: Youth Media Practices...

backgrounds (family tradition, education, peer-group, partnership etc.) "tend to become differently 'familiar' to media technologies" even though they share the same "media-generation-as-actuality" (Lepa et al., 2014; Mannheim, 1952). This is close to Pierre Bourdieu's concept of habitus as socially inscribed "system of durable dispositions that an individual has internalized through family upbringing and education and in relation to the surrounding society, and which imposes on the individual a specific disposition to act" (Bolin \& Skogerbø, 2013: 9). In that sense we can assume the existence of different types of mediatized habitus that share certain common discourse on media. The change of focus from the household or family to the individual user as a member of a family, household and different other lifeworlds reflects the change toward ever more personal, individually used, mobile and corporeal media. The situated character of media use also implies broader conceptualization of the use of media and information and communication technologies (ICT) as a social practice (Couldry, 2012, 2010; see also Brauchler \& Postill, 2010; Reckwitz, 2002; Schatzki 1996) where communication media are routinely used as a resource in order to address the challenges of everyday life in contemporary complex late modern (Giddens, 1991) societies.

The third assumption refers to the temporal, social and spatial context of everyday practices. Everyday spaces of media use structure temporal experiences through spatial design, architecture, size, and material infrastructure, including available media and communication technologies. They are structured (like time) "in the activity of perceiving them, occupying them, or passing through them"(Silverstone, 1993: 288, see also De Certeau, 1984). In important ways 'dailiness' is revealed as a more complex temporal experience than one simply (re)produced in the interplay between the production of a broadcast program and its integration within the recursive texture of everyday life. It is reproduced through daily contact with the complex media environment, its dominant temporal orientation manifested in its constant flows (Castells, 2000, Crary, 2013), speed and immediacy (Tomlinson, 2007) and negotiated by actors (with different dispositions -habitus) in the context (temporal, spatial, and social) of different everyday practices. The complexities of 'dailiness' will be described through the temporal genres of media use. In the next section, I will briefly present the empirical research, the notion of genres as a basis for the typology of temporal experiences, and the identified genres of media use.

\section{Mediatized Temporal Experiences and Genres of Media Use}

The findings presented here are based on the qualitative interpretative analysis of the media use diaries and autobiographical reflections on media use written by 64 students ( 5 male, 59 female) of the first year of the graduate study of journalism at 
the Faculty of Political Science in Zagreb. This is a self-generated sample of students who consider themselves technologically skilful users of new media (intensity sample). The intensity sample consists of the cases that "manifest the phenomenon of interest intensely (but not extremely)", because extreme cases may be too unusual and they may distort the manifestation of the phenomenon of research interest (Patton, 2002). This group of students wrote media use diaries and autobiographical reflections where they reflect on their diaries in more detail. They described their experiences with different media and the patterns of media use within their families. Media use diaries were written in a period of two weeks at the end of October 2011 (21-31 October). Participants were instructed to enter all instances of contacts with media and communication technology during the day and to describe them in detail. Diaries were written every second day from the $21^{\text {st }}$ of October to the $1^{\text {st }}$ of November, while the participants had one day to reflect on what was written in the diary.. Autobiographical essays were written several times in the period from October 2011 to February 2012. The themes from diaries and essays were also discussed with the subjects within a seminar group and via emails and instant messages (e.g. gtalk).

Communication diaries provide the basis for genre identification, while autobiographical essays on subjects' personal, as well as their family's media practices were additionally analysed to identify empirical types of users in terms of characteristics of family or household (values, interactions, media use, material geography of home). The factors that proved important for determining the type of mediatized habitus were: availability of new technologies, participative family culture, and availability of time and space for individualized experiments with new technology (similar as in Ito et al., 2010). Three types of mediatized habitus were identified within this study: network type, hybrid type, and constrained type. They developed different typical practical and habitual orientation to time and media and communication technologies: the network type generally developed more sophisticated technological skills compared to the hybrid and especially to the constrained type. The network type adopted a dominant temporal orientation to a greater degree, when compared to the other two types, especially to the constrained type. They are more flexible and oriented toward constant flows from communication technologies then other two types. The constrained type tends toward more sequential patterns of time and media use. They place more emphasis on traditional media - television and print media - while the hybrid and network types give more significance to new media, especially social network sites and smartphones (mobile internet). Nevertheless, all types, especially the networked and hybrid type, look at the new media as a tool for handling different day-to-day activities that is "fast", "cheap" or "free of charge", "always present", "easily accessible" and "always with them". Networktype users tend to describe contemporary life in terms like "busy", "fast", and "hur- 
'Dailiness' in the New Media Environment: Youth Media Practices...

ried". They see the age of new media as a stressful and fast-paced time, which is caused by our ,depend[ence] on them" (Lina). Nino wrote: "Media make me dependent on them, the more time I spend online, the more time I need to be online. When I am not online for a while, I no longer have the need to be online (Nino)." On a manifested level, this feeling is associated with the usage of new media, which is also the reason why many users try to limit their usage of new media to particular locations, situations, or times of the day: "Coffee with friends, evening walk, playing basketball on Sundays. In these places I do not want media at all" (Iva). However, if we look at the implicit level, busy and hurried life, which is closely related to the feeling of lack of time, is associated with the pressures arising from different spheres of their life: studying, work, family life, friendship, romance, and other sphere of interest, while new media usually serve as the main culprit for all negative consequences of such a lifestyle: "Sometimes I don't have time to meet friends, due to our busy schedules, and we are forced to communicate through the Internet. I don't like this and this is why I try to reduce online contact with close friends and to communicate with them directly...I think that they make people more distant toward each other...I consider the Internet dangerous if its consumption is not carefully dosed, because it easily causes passivity. For example, you have shorter and shorter articles on the web-people don't want to read one text for 10 minutes...I have a feeling that people today just superficially scan newspaper titles... and this is enough for them - they supposedly know what is going on but they actually don't have the first idea about what it says in the text" (Marta). Apart from such general subjective views on the role of new media use for the experience of time, the focus on temporal genres of media use (presented in the following chapter) will give us a more detailed and structured picture of everyday mediatized temporal experiences (re)produced through everyday contacts with media.

\section{Focusing on the Genres of Media Use}

The notion of genres provides a flexible interpretative tool for the analysis of media use in the context of everyday life. The concept of genre implies an active and recursive relationship with the environment, which is in line with the meta-theoretical assumptions presented earlier in the article. The first application of the concept of genre $^{2}$ to extra-verbal or non-linguistic operations like walking, cooking or media use is made by French cultural theorist Michel de Certeau (1984). Within media studies, the concept of genre was used for the analysis of Internet use by Canadian media scholar Maria Bakardjieva (2005) and by Mizuko Ito (2010) and her research team from the University of California, Berkeley who used the notion of "participation genres" to describe engagement of youth with online media. However, this paper seeks to address the impact of media use on the temporalities of everyday life, 
using the concept of genres to enable identification of different types of mediatized temporal experiences. Thus, temporalities are seen as (re)produced through contacts with communication media within different social practices. In order to act, social actors have to "master and appropriate the mediational means" or "cultural tools" like technology, language, and other material and symbolic elements of culture, while the practical definition of a cultural tool "is revealed in the isolated acts of use" (Bakardjieva, 2005: 27; Wertsch, 1991). The notion of genre implies an active role of the user, and emphasises "process of interpretative recognition" where users recognize certain structural aspects of a situation (temporal affordances of media) and act on them "in a social, routinized way" (Ito et al., 2010: 15). Media use is thus a "social event" (Voloshinov, 1986: 94) or "speech act" as a part of social interaction, by means of communication technology and within particular social practice (Couldry, 2012, 2010; see also Brauchler \& Postill, 2010; Reckwitz, 2002; Schatz$\mathrm{ki}, 1996)$. At the same time, this event is "a moment in the continuous process" of social interaction "accompanying the all-inclusive social reproduction of a given human collective" (Bakardjieva, 2005). Media use thus cannot be understood and explained outside of the connection with a concrete situation and the respective social practice. They also "cannot be dissociated from the existence of the subjects who are their agents and authors (Bakardjieva, 2005: 27). Within the context of different social practices certain typical genres of media use emerge, stabilize and change, while also (re)producing the texture of society and its temporalities. Genre here is defined as typified (social) action "in the context of socially defined recurrent situations" (Yates \& Orlikowski, 1992: 301) and historically and culturally shaped, specific, and complex solutions to practical problems (Gunther \& Knoblauch, 1995: 8). Genres are in that sense a form of social (intersubjective) knowledge (Yates \& Orlikowski, 1992: 301). The concept of genre is here applied to the recognized types of media use, describing the different ways people use media in different situations.

Different temporal genres of media use have a certain internal and external structure, and situative level (Yates \& Orlikowski, 1992: 301). The "internal structure" refers to the general pattern of the components of a certain usage genre (verbal and non-verbal activities). The "external structure" describes the elements of the particular genre, including also the types of participants involved, while "situative level" refers to the particular situation or context within which a certain genre occurs (walking, shopping, leisure, work, etc). The internal structure of genres will be analysed in terms of clocking and orientation (Silverstone 1993a, 1994). Orientation refers to the general "reference points in time" (past, present or future) which individuals use to "conduct [their] affairs" (Silverstone, 1994: 36). It is "relatively invisible in terms of actual practices" but is structuring them toward past, present or future (Silverstone, 1993a: 301). Orientation involves both "intention and justifica- 
tion" of "actions or patterns of actions" (Silverstone, 1994: 36). The basic assumption here is that individual (and) family temporal orientation is "profoundly influenced by the dominant temporal orientation of public culture", which is "fundamentally and increasingly, being geared to the present" (Silverstone, 1993a: 298-9), determined by spaces of flows (Castells, 2000) and is inscribed in information and communication technologies. According to Silverstone (1993a, 1994), individuals and their families mediate dominant public temporalities within and through their own temporal agendas, which "require skills or cultural competences to sustain their ambitions" (Silverstone, 1993a: 300). Clocking refers to the practical engagement with time (Silverstone 1993am 1994). It is manifested "in the regulation of sequence, frequency and pace of immediately experienced events from moment to moment" and "entails a whole set of activities which in turn involve sequencing and setting of frequency, duration and scheduling" (Silverstone, 1994: 36). Practical engagement with time (clocking) is gender-, age-, and class-based, and is dependent on pressures from outside (demands of work, travel, duty etc.). It is uneven in quality (fragmented and interrupted or consistent and uninterrupted). It can be experienced individually or socially, as "unsynchronized or synchronized", "wasted or filled". Every instance of contact with media and communication technology written in media use diaries was analysed in terms of its: a) internal structure (temporal orientation toward the past, present or future and practical engagement with time); b) external structure (types of participants, types of communication media); and c) situative level or context within which a certain genre occurs. Six temporal genres or typical temporal orientations of media use are identified on the basis of communication diaries. These genres are: slowing down, flow management, time machine, orienting toward public flows, going with the flow, orienting toward personalised flows. An individual may engage with multiple genres in a situationally specific way. At the same time, all identified genres were found in each analysed individual diary. Nevertheless, particular genres or their subgenres are typical for certain types of users.

The genre labelled as slowing down refers to media use in which users create moments of "slower time". This genre often occurs in the moments before or after certain "hot spots" (Southerton, 2009) during the day: "When I come home after a really hard day, I immediately sit in front of the TV."This genre is usually based on the usage of traditional media and more conservative practices like watching a movie, watching television or reading books. Home is the typical location where this genre takes place.

Network and hybrid types of users more often watch a favourite movie or series on their laptops or desktops, or rarely on tablets and mobile phones ${ }^{3}$. When they wish to create a more special and slower time, they watch downloaded content on the biggest screen in the living room (often in company). Nevertheless, the network 
type of users are more oriented toward individualised and mobile media for slowing down the time, while hybrid and constrained users prefer to create slower time in a more traditional way (by reading books, watching a movie on TV, etc.). Certain exclusive moments (and places) during the day, week or year are regularly marked as time-places of slower time, such as family cottages in the countryside, weekends, and vacations: "when I come back home, after a vacation (where I usually don't watch TV or listen to the radio, and I'm not active on social network sites), I realise that I don't need any of these media, but on the other hand, it is so easy to get used to them when I return to my everyday life". Typically, these locations are consciously placed off-the-grid, either completely or to some extent. In the subjects' narratives, these time-spaces of peaceful life were often articulated as rare and ever more jeopardized examples of the effort to escape from the hurriedness and fast-paced nature of ordinary life. New media are only occasionally present, their use is limited, or they are entirely absent from these places. Traditional and more conservative media practices are used here in order to create time-spaces for reflection, relaxation, or community and sharing time with loved ones, friends and family. Use of traditional media, especially print media, is generally associated with a time of relaxation. For example, one student wrote in her essay that she read books "when I have a lot of spare time" and lifestyle magazines "when I have nothing special to do", like "during summer, on the beach". In some cases, uses of new media can create "slow time", for example "chatting with friends". Media within these genres also serve as a tool to fill moments of slow time with the produced content, indicating the pressures from the public flows. The genre of slowing down entails solitary as well as social activities. Typical companions within this genre are close friends, family, or romantic partners. Orientation of this genre is usually toward the past, or toward the "freezing of time" (Silverstone, 1993: 301), but at the same time it is constantly threatened by the intrusive presence of constant public and private flows. Nevertheless, turning media off in some cases serves as a temporary means of slowing down the fast-paced nature of contemporary life.

The time machine genre designates different practices of saving, restoring, or keeping certain moments in time by means of communication technologies, like taking, storing, and watching photographs or family video. These practices could be individual or shared. The temporal orientation of these practices is mostly toward the past. Self-expressive practices of writing statuses on Facebook, Twitter or other social network sites, or blogs also serve as a tool for keeping memories of distinct moments in time, which is supported by the ability to store and replicate messages (Baym, 2010). For example, Facebook's Timeline service is based on this genre. Watching movies, cartoons, TV shows, or listening to music from earlier periods in life, usually through YouTube, encapsulate another way of capturing or bringing back time by means of communication media. This genre shows up in communica- 
tion diaries of all respondents, but it is more prevailing in the daily life of networked users, who are more open to new technologies. Constrained users avoid using social networks as a remembering and self-expressive tool. Instead, they choose services (texting, email) which enable communication within closed circles to maintain the distinction between the private and the public sphere within new situational geography (Meyerwitz, 1985) of mediatized societies. This distinction is even more threatened, among other factors, by the proliferation of social network sites and social pressures toward their usage. Even though this genre is in some aspects similar to the genre of flow management (described below) - for example in the case of storing something for later use), the purpose of (re)storing something within this genre is different. Compared to the flow management genre, where a person stores or postpones certain conversation, message, or email for later use in order to avoid the disruption of some activity in the present, the time machine genre is related to individual or collective identities, continuity, and memory.

The issue of security and surveillance emerged as the most important social consequence of this genre for the research participants. New technologies enable storage and restoration of gathered symbolic content and information that reveal users' identities in technical, but also in cultural, social, and emotional terms. This personal data is easy to trace within the digital, networked and converged media environment. The security issue was the most important to the constrained type of users, and it proved to be one of the major obstacles preventing them from using new technologies more extensively. The networked type of users are more concerned with the problem of overabundance caused by the pervasive use of digital media for keeping memories, which leads to additional stress because they do not have enough time to keep track of them. At the same time, network-type users do not put so much practical emphasis on the security issue, but they are mostly unaware of the way in which these practices, comprised by the time machine genre, serve as self-disciplinary instruments which put pressure on them to calibrate their offline with their published online identity. In some cases they discursively recognize this issue as problematic, but also see it as a necessary consequence of life in a digital environment. Nevertheless, they find themselves competent enough to deal with the security and privacy issues. What is revealing here is the tension that exists between pressures toward reflexivity on one side (Giddens, 1991), and self-disciplinary (Foucault, 2013, 1994) consequences of mediatized practices on the other, also pointing to the need for further theoretical elaboration, reconsideration and potential hybridization of these two confronted perspectives (Gauntlett, 2002). The genre of orienting toward general public flows relates in part to the regulative type of use (structural uses of television) as described by James Lull in his typology of social uses of television (1980: 201-206). Television or radio are often employed as "environmental resources" providing not only "constant background noise" or "company 
for accomplishing household chores and routines" but also serve as a "behavioural regulator" punctuating "time and family activities" (1980: 201). This genre is the closest to Scannell's (1996) concept of 'dailiness'. Public flows here provide structure to the fragmented and unstructured practices of using new media, such as "surfing the net", "visiting Facebook" or "chatting with friends". Television or radio helped subjects to keep up with the social time, by imposing an external structure of relevance to subjective time. The typical location where this genre takes place is at home, but it is also evident in public places and situations "on the go" (Green, 2002). We can find another version of this genre in cases when people go with their laptops to work at the cafe where radio keeps playing. In this case it is not just the radio, but also the movement of other people present there that punctuates time spent working on the laptop. What is evident from this genre is the tendency to calibrate domestic and subjective temporal experiences, with the social flows mediated by communication technologies. Furthermore, two types of regulation were detected. One refers to the structuration of the ordinary, routine and often boring activities like chores while the other refers to the self-imposing of social time during purely social or pleasant activities, which are in their own right often described as "wasting time" or "losing time". Our daily practices in using media illustrate the mechanisms by which social time is self-imposed, equally structuring pleasant activities like chatting with friends on Facebook and relatively dull, boring and unpleasant activities like chores. In the latter case, though music or familiar voices from the radio can make this routine and boring activity more pleasant, we are actually pushed to act within the framework of public or social time (Leccardi, 2003; Castells, 2000; see also Crary, 2013). In the case of Facebook, the situation seems more 'natural' because this practice is considered a 'waste of time', suggesting that (self)disciplineis here'justified'..

Public flows also serve here for orientation in adapting to the environmental aspect of social life: "usually I listen to the radio to be informed about the traffic conditions and weather forecast, to find out what to wear and what kind of weather to expect during the day." Nevertheless, broadcast media are not the exclusive tool for orientation to the public flows: "I have my meal alongside Večernji list, which I read while eating. I re-read about current events, remind myself that the weather forecast for today is quite bad, and then I go back to my room (Maja). "Another subgenre here represents the practice of watching the daily informative program (alone or with family) or reading news (online or printed). In the last three examples we are not dealing with the regulative use of media in a narrow sense (Lull, 1980), but with the orientation to public flows which is in line with Scannell's (1996) concept of the world of shared concern. The dominant temporal orientation of all described subgenres is toward the constant flux of spaces of flows that are saturating life-world of individuals in mediatised societies. 
Orienting toward personalized flows: This genre could be divided into two subcategories: the first one refers to private spaces like homes and cars, while the second one occurs in public outdoor and indoor spaces. In contrast with the regulative use of broadcast media within the genre described above, in this case subjective (internal) references are imposed on the external environment and the person seeks to adapt the current environment to internal moods or desirable atmosphere. For example, within this genre a person will choose a niche radio or TV station, or selected personalised music list on an mp3 player or YouTube: "I'm going on YouTube to select some relaxing music while I'm reading a new post from my favourite blogger". A more public version of this takes place in public transport or on the city streets where subjects use different media (usually mobile phone, smartphone, or mp3 player) in order to "pass the time", "kill time", "make it go faster" or "make it safer". The most usual practice among research subjects was listening to mp3 music on their mobile phones, as they move through the city: "I listen to the radio... only while riding in public transportation, to pass the time and make boredom not last as long. I usually listen to music on FM Radio or Totalni FM".

Only a few of them read books or newspapers while using public transportation. Subjective and public orientation sometimes merge, which is provided by the affordances of mobile media. For example, there are situations when a person listens to a live radio program while reading book in public transportation, or just walking down the street. In that case radio serves two purposes. Radio provides background noise and helps to make time "on the go" more cosy, but at the same time it gives structure and punctuates time spent in reading books, while reminding the person of the social time and providing temporal orientation for the subjective passage of time. The dominance of social time over subjective time is evident here. Another subgenre within the genre of orienting toward personalised flows occurs when a person is oriented toward personalized flows of information from sources like Facebook, personalized subscriptions to online news etc: "In the morning, when I wake up and if I don't have any obligations, I spend at least half an hour on Facebook, and in the meantime I browse through my favourite portals or online newspapers, while I listen to a few songs on YouTube. This is the ideal morning because I recharge my batteries for my busy daily schedule (Marija)". This is an example of a combination of the genres orienting toward general public and personalised flows. Another interesting example of the genre of orienting toward personalised flows is from Marina's diary where she wrote the following comment: "I often chat with my brother through Facebook, even though his room is right next to mine. Sometimes it is easier to write him something on the Facebook chat than to get up from the computer and walk to his room" (Martina). Here we witness how access to continuous flows from digital media has advantage over direct physical contact with the close ones, also revealing the dominance of "spaces of flows" over places (Castells, 2000). 
Both genres, orienting toward general public and orienting toward personalized flows are articulated as means for "passing time" or "killing time" spent in travelling between two locations or when waiting for something: "All this is thanks to my smartphone, which allows the time spent in public transportation, or waiting at the doctor, or waiting for the end of lectures, to pass more quickly (Martina)".

Flow management refers to the genre where actors attempt to take control over imposed temporal, spatial and social structures of relevance. This genre covers activities like managing relationships with different people, which involve, for example, simultaneous media practices, practices of "micro-coordination" (Ling \& Yittri, 2002), holding or rejecting calls, postponing communication (email, text, voice call etc.), downloading, recording and saving something (a photo, a movie, a series, an e book etc.) for later use. Flow management is also applicable to the practices of delegating different tasks to communication technologies (Horning et al., 1999: 294) in order to free-up time. This genre is based on different technical features of digital technology like answering machines, caller identification services (Licoppe, 2008), alarm clocks, location services, body monitoring and others. These features rely on the asynchronicity, storability and replicability of digital media (Baym, 2010). As an unintended consequence, this genre produces additional temporal pressures, such as a full inbox, too many new messages, posts or tweets to read, etc. This is the most mobile genre, though it frequently takes place at subjects' homes. In such cases, the home serves as a mediarich headquarters for managing different life-worlds (Hepp, 2012).

Even though this genre appears future-oriented at first glance, its underlying orientation is toward the present in two senses. At the same time within this genre individuals strive to free the present for some other more "important" or "wishful" activity, while constant flows from their always-on, always carried media and communication devices put pressure (also inscribed in different technological features, such as notifications) on them, demanding permanent and instant reactions. Shutting down everything represents one way, but always very temporary, of dealing with such a pressure. This genre is justified by a sense of control, though it usually ends up with frustration. Besides, it reveals how our dependencies on information and communication technologies are structurally produced and inscribed into technology, and are not the result of the individual's failure or psychological traits.

Going with the flow: this genre was the most rarely mentioned in communication diaries. This genre refers to situations of withdrawal from the immediate environment into virtual worlds or situations where subjects are forced to follow specific technologically imposed sequences and procedures, for example downloading a movie or formatting a hard disk. The distinctive characteristic of this genre is that the person feels "completely lost in time" or "forgets about time". Except for games, this mode is typical for chatting with friends or surfing the net. Sometimes, even 
though there is some other media in the background serving a regulative function (regulating temporalities), a person totally loses a sense of the surrounding time and space and just goes with the flow. There were also cases when a similar thing happened to a person when he or she was reading a book. Only a few subjects mentioned playing online games during the observed period but many of them nevertheless mentioned this in autobiographical essays. This genre also has an implied moral aspect and subjects admitted they try to discipline themselves and regulate time spent in this mode, which points to the contradictions inscribed in our mediatized cultures, deeply dependent on information and communication technologies.

\section{Conclusion}

Genres presented here reveal the deep mediatization of our temporal and spatial experiences and the technological dependence of our contemporary late modern cultures. They reveal contradictions of 'dailiness' (re)produced through everyday contacts with media. 'Dailiness' is confirmed as a more complex temporal experience than one simply (re)produced in the interplay between the production of the broadcast program and its integration within the recursive texture of everyday life (Scannell, 1996). It is reproduced through daily contact with the complex media environment and its dominant temporal orientation (Silverstone, 1993a, 1994), which is manifested in its constant flows and negotiated by actors (with different dispositions - habitus) in the context (temporal, spatial, and social) of different everyday practices. Complexities of 'dailiness' are described through the six temporal genres of media use: slowing down, flow management, time machine, orienting toward public flows, going with the flow, and orienting toward personalized flows. These genres are described through their underlying temporal orientation, clocking, typical activities, media repertoires, locations, actors, and situations. The identified temporal genres do not necessary comprehend the entire empirical temporal dimension of media use in the context of contemporary complex late modern societies, or even within the context of post-socialist societies, like Croatia (Peruško et al. 2014). The study is based on the self-generated intensity sample which consists of cases that "manifest the phenomenon of interest intensely (but not extremely)", because extreme cases may be too unusual and they may distort the manifestation of the phenomenon of research interest (Patton, 2002). Though unusual, extreme cases could reveal some different temporalities in relation to media use. Besides, female users are overrepresented within the sample, as a result of the gender structure of students of journalism at the Faculty of Political Science in Zagreb. Due to the gendered nature of clocking as an important aspect of temporal genres of media use, we could assume the occurrence of different genres in sample with amore even share of male users, as would be the case if we changed focus toward other age groups. Fur- 
thermore, the empirical material is five years old, and in the meantime some important changes of technologically enabled "spaces of possibilities to perceive and act on the environment" (Lepa et al., 2014: 209) occurred (for example, spread of the mobile applications), which could potentially generate new temporal genres of media use. We should also take into account changes within the Croatian media system in the last five years, especially within the telecommunications market, with more affordable offers of smartphones, tariff options and broadband, together with an increase in the quality of wireless connection. Nevertheless, genres presented in the paper give insight into the ways in which the dominant temporal orientation of contemporary late modern societies (Silverstone, 1994, see also in Crary, 2013) is negotiated, resisted, confirmed and managed in actual day-to-day contacts with media.

Young people, who perform these genres, are seen as socially and historically embedded social actors (Silverstone, 1993a, 1994; Mannheim, 1952). They have developed different typical habitual orientations toward time and to media and communication technologies. The availability of information and communication technologies, the availability of time and space for individual experiments with technology, together with participative family culture were confirmed as the most important factors determining the type of habitus (Ito et al., 2010). This also points to the discussion about "an uneven landscape of power in which mediatization processes take place" (Lundby, 2009: 9), which is also an important subject for further elaboration. The differences among three identified types of users - network, hybrid, and constrained - have important consequences for the competences and skills of young people to negotiate dominant imposed temporalities inscribed into the contemporary media ecology. The result reveals strong pressures, especially among the network type toward the "constant presence" (Turkle, 2008) and access to public social or personalized flows, manifested as an urge to check "what's new" or "what's going on" on Facebook, news portals, email, etc. Pressures to coordinate different spheres of life (family, friendship, education, work, etc.), together with the increased mediatization of these spheres, result in the tendency to adopt services like Facebook and technologies (smartphone) which afford multifunctionality, ease, accessibility, and flow management. At the same time, these practices produce ever more flows to manage. The consequences of this process are manifested as a "feeling of dependency" on these services and devices but also as a feeling of stress, fast-paced and hurried life, impossible to escape from. In contrast, the constrained type suffers less from the consequences of flow overabundance. They are consciously or structurally excluded from some "spaces of flows" (Castells, 2000), which could potentially affect their life opportunities in the contemporary mediatized social environment. Furthermore, genres like slowing down and time machine also reveal the ambivalences related to the role of traditional media practices as a form of resistance to the dominant temporal orientation, calling for further elaboration of the significance of these practices. The risks of this process with regard to everyday temporalities 
are related to the convergence of media and the tendency among users toward multifunctional services and devices. This potentially leads to increasing difficulties for users in resisting pervasive flows which orient them toward a "constant present" undermining the plurality and richness of temporalities of the life-world. Beside, the genres orienting toward public and personal flows illustrate the mechanisms by which social time is (self-) imposed on us, structuring both pleasant activities such as socializing, and those we conside boring andr elatively unpleasant, such as household chores. While making some of these activities easier to perform, the presence of media tricks us into patterns of socially-imposed time. This challenges the assumption that contemporary late modernity affords increased personal freedom with its seeming wealth of opportunities for adapting social time to subjective time.

Taking into account the methodological shortcomings we discussed, the theoretical framework suggested in the paper, together with the typology of temporal genres of media use and types of mediatized habitus proved as useful tools for a better understanding of everyday temporal experiences in the mediatized life-world. Hopefully, this will shed a little light on the still-uncharted territory within media and communication studies.

\section{ENDNOTES}

1 Generation-as-actuality refers to theconcept of generational unit by German sociologist Karl Mannheim (1952). According to Mannheim, "Members of neighbouring cohorts will-ideally-experience same or very similar media technology possibility spaces and are therefore prone to share... general impressions of 'what media may afford 'them " (Lepa et al., 2014: 210). Media-generation-as-actuality thus represents "a form of discursive bond", which is not dependent "on actually shared "existential' social practices and deep engagement with the according media” (Lepa et al., 2014: 210).

2 De Certeau (1984) is drawing on Bakhtin's concept of "speech genre”. Bakardjieva's (2005) conceptualization of technology use as language-speech also relies on the school of cultural psychology which is grounded on the work of Russian philosophers of language Valentin Nikolaevich Voloshinov and Mikhail Mikhailovich Bakhtin (Wertsch, 1991, 1998; Wertsch et al., 1995; see also in Bakhtin, 1986; Vološinov; 1986) and on the work of Michel De Certeau (1984).

3 Even though most of the subjects had smartphones, only a few of them used Internet services, and they used them in a limited way due to relatively expensive tariff options for data services on the Croatian market within the observed period.

\section{LITERATURE}

Bakardjieva, M. (2005) Internet society: The Internet in Everyday Life. London, Thousand Oaks \& New Delhi: Sage Publications.

Bakhtin, M (1986) Speech Genres and Other Late Essays. Austin: University of Texas Press. 
Medij. istraž. (god. 22, br. 1) 2016. (65-86)

Baussinger, H. (1984) Media, technology and daily life. Media, Culture, and Society, Los Angeles, London, New Delhi, Singapore and Washington DC, 1984(6): 343-351.

Baym, N K (2010) Personal Connections in the Digital Age. Cambridge \& Malden: Polity Press.

Bell, D. (2007) Cyberculture Theorists. Manuel Castells \& Donna Haraway. London \& New York: Routledge.

Berger, P. \& Luckmann T. (1992) Socijalna konstrukcija zbilje. Zagreb: Naprijed.

Berker, T., Hartmann, M., Punie, Y. \& Ward, K. J. (eds.) (2006) Domestication of Media and Technology. Maidenhead: Oxford University Press.

Bolin, G. \& Skogerbo, E. (2013) Age, generation and the media. Nothern Lights: Film \& Media Studies Yearbook, New York, 11(1): 3-14.

Bräuchler, B. \& Postill, J. (eds.) (2010) Theorising Media and Practice. New York \& Oxford: Berghahn Books.

Castells, M. (2000) Informacijsko doba: Ekonomija, društvo i kultura. Svezak I: Uspon umreženog društva. Zagreb: Golden Marketing.

Couldry, N. (2012) Media, Society, World. Social Theory and Digital Media Practice. Cambridge \& Malden: Polity Press.

Couldry, N. (2010) Theorising media as practice, pp. 35 - 54. In: B. Bräuchler \& Postill, J.: Theorising Media and Practice. New York \& Oxford: Berghahn Books.

Crary, J. (2013) 24/7: Late Capitalism and the End of Sleep. London: Verso.

Cuvalo, A. (2015) Media Life of Youth: Application of the theory of practice to the analysis of media habits in multimedia environment. Unpublished doctoral dissertation.

De Certeau, M. (1984) The Practice of Everyday Life. Berkeley, Los Angeles \& London: University of California Press.

Deuze, M. (2012) Media Life. Cambridge \& Malden: Polity Press.

Elias, N. (2007) Što je sociologija? Zagreb: Antibarbarus.

Foucault, M. (2013) Povijest seksualnosti 1. Volja za znanjem. Zagreb: Domino.

Foucault, M. (1994) Nadzor i kazna: rađanje zatvora. Zagreb: Informator/Fakultet političkih znanosti.

Gauntlett, D. \& Hill, A. (1999) TV Living. Television, Culture and Everyday Life. London \& New York: Routledge \& British Film Institute.

Gibbson, J. (1986/1979) The Ecological Approach to Visual Perception. Boston: Houghton Mifflin.

Giddens, A. (1991) Modernity and Self-Identity. Self and Society in the Late Modern Age. Cambridge: Polity Press. 
'Dailiness' in the New Media Environment: Youth Media Practices...

Giddens, A (1984) The Constitution of Society. Berkley \& Los Angeles: University of California Press.

Gitlin, T (2007) Media Unlimited. Revised Editon: How the Torrent of Images and Sounds Overwhelms Our Life. New York: Metropolitan Books.

Green, N. (2002) On the move: Technology, mobility, and the mediation of social time and space. The Information Society, Philadelphia, 18(2002): 281-292.

Günthner, S. \& Knoblauch, H. (1995) Culturally patterned speaking practices - the analysis of communicative genres. Pragmatics, Amsterdam, 5(1): 1 - 32.

Haddon, L. (2007) Roger Silverstone's legacies: domestication, New Media \& Society, London, Thousand Oaks \& New Delhi, 9(1): 25-32.

Hartmann, M. (2013) From Domestication to mediated mobilism. Mobile Media \& Communication, Los Angeles, London, New Delhi, Singapore \& Washington DC, 1(1): 42-49.

Harvey, D. (1989) The Condition of Postmodernity. Oxford: Blackwell.

Hasebrink, U. \& Domeyer, H. (2012) Media repertoires as patterns of behaviour and as meaningful practices: A multimethod approach to media use in converging media environments. Participations, Aberystwyth, 9(2): 757 - 779.

Hepp A (2012) Cultures of Mediatization. Cambridge: Polity Press.

Hjarvard, S. (2013) The Mediatization of Culture and Society. London \& New York: Routledge.

Hörning, K. H., Ahrens, D. \& Gerhard, A. (1999) Do technologies have time?: New practices of time and the transformation of communication technologies. Time \& Society, London, Thousand Oaks \& New Delhi, 8(2): 293-308.

Ito, M., Baumer, S., Bittanti, M., Cody, R., Herr-Stephenson, B., Horst, H. A., Lange, P. G., Mahendran, D., Martínez, K. Z., Pascoe, C.J., Perkel, D., Robinson, L., Sims, C. \& Tripp, L. (2010) Hanging Out, Messing Around \& Geeking Out. Cambridge: MIT Press.

Jameson, F. (2003) The end of temporality. Critical Inquiry, Chicago, 29(4): 695 - 718.

Keightley, E. (2013) From immediacy to intermediacy: The mediation of lived time. Time \& Society, London, Thousand Oaks \& New Delhi, 22(1): 55 - 75.

Latour, B. (2005) Reassembling the Social: An Introduction to Actor-Network Theory. Oxford \& New York: Oxford University Press.

Leccardi, C. (2003) Resisting 'acceleration' society. Constellations, New York, 10(1): 34-41.

Licoppe, C. (2008) The mobile phone ring, pp. 139 - 153. In: J. Katz: Handbook of Mobile Communication Studies. London: The MIT Press.

Licoppe, C. (2004) 'Connected' presence: the emergence of a new repertoire for managing social relationships in a changing communication tehnoscape. Envi- 
Medij. istraž. (god. 22, br. 1) 2016. (65-86)

ronment and Planning D: Society and Space, London, Thousand Oaks \& New Delhi, 22(1): 135 - 156.

Ling, R. \& Yittri, B. (2002) Nobody sits at home and waits for the telephone to ring: Micro and hyper-coordination through the use of the mobile telephone, pp. 139169. In: J. Katz \& M. Aakhus: Perpetual Contact: Mobile Communication, Private Talk, And Public Performance. Cambridge \& New York: Cambridge University Press.

Linke, C. (2013) Mobile media and communication in everyday life: Milestones and challenges, Mobile Media \& Communication, London, Thousand Oaks \& New Delhi, 1(1): 32-37.

Lister, M., Dovey, J., Giddings, S., Grant I. \& Kieran, K. (2009) New Media. A Critical Introduction. Second Edition. London \& New York: Routledge.

Livingstone, S. (2004) The challenge of changing audiences: Or, what is the audience researcher to do in the internet age? European Journal of Communication, London, Thousand Oaks \& New Delhi, 19(1): 75-86.

Livingstone, S. \& Bovill, M. (1999) Young People, New Media: Report of the Research Project Children Young People and the Changing Media Environment. Research report, Department of Media and Communications, London School of Economics and Political Science, London, UK (online). Available at.: http:// eprints.lse.ac.uk/21177/.

Lull, J. (1990) Inside Family Viewing: Ethnographic Research on Television's Audiences. London \& New York: Routledge.

Lull, J. (1980) The social uses of television. Human Communication Reasearch, 6(3): $197-209$.

Lundby, K. (2009) 'Introduction. 'Mediatization' as key”, pp. 1-18. In: Lundby, K.: Mediatization, Concept, Changes, Consequences. New York: Peter Lang.

Meyrowitz, J. (1985) No Sense of Place. The Impact of Electronic Media on Social Behaviour. New York: Oxford University Press.

Moores, Sh. (2005) Media/Theory. London: Routledge.

Moores, Sh. (1988) „The Box on the dresser“: Memories of an early radio and everyday life, Media, Culture \& Society, Los Angeles, London, New Delhi, Singapore \& Washington DC, 10(1): 23-40.

Morley, D. (2003) Home Territories. Media, Mobility and Identity. London \& New York: Routledge.

Nansen, B., Arnold, M., Gibbs, M. R. \& Davis, H. (2009) Domestic orchestration: Rhytms in the mediated home. Time and Society, Los Angeles, London, New Delhi, Singapore \& Washington DC, 18(2-3): 193 - 208.

Patton, M. Q (2002) Qualitative Research \& Evaluation Methods (3 ${ }^{\text {rd }}$ ed.). Thousand Oaks: Sage. 
'Dailiness' in the New Media Environment: Youth Media Practices...

Peruško, Z., Vozab, D. \& Čuvalo, A. (2014) Digital mediascapes, institutional frameworks and audience practices across europe. International Journal of Communication, Los Angeles, 9(2015): 342 -364.

Reckwitz, A. (2002) Toward a theory of social practices. A development in culturalist theorizing. European Journal of Social Theory, Los Angeles, London, New Delhi, Singapore \& Washington DC, 5(2): 243 - 263.

Scannell, P. (1996) Radio, Television, and the Modern World. Oxford \& Cambridge: Blackwell Publishing.

Schatzki, T. R. (1996) Social Practice. A Wittgensteinian Approach to Human Activity and the Social. Melbourne: Cambridge University Press.

Schutz, A. \& Luckmann, T. (1973) The Structures of the Life-World. Evanston: North-Western University Press.

Silverstone, R. (1994) Television and Everyday Life. London: Routledge.

Silverstone, R. (1993a) Television, ontological security and the transitional object. Media, Culture and Society, Los Angeles, London, New Delhi, Singapore \& Washington DC, 15(4): 573 - 598.

Silverstone, R. (1993b) Time, information and communication technology and the household. Time \& Society, Los Angeles, London, New Delhi, Singapore \& Washington DC, 2(3): 283 - 311.

Silverstone, R. \& Hirsch, S. (1992) „Introduction“, pp. 1-14. In: R. Silverstone \& E. Hirsch, E.: Consuming Technologies. Media and Information in Domestic Spaces. London \& New York: Routledge.

Southerton, D. (2009) „Re-ordering temporal rhythms. Coordinating daily practices in the UK in 1937 and 2000“, pp. 49-63. In. E. Shove et al.: Time, Consumption, and Everyday Life. Practice, Materiality, Culture. Oxford \& New York: Berg.

Tomlinson, J. (2007) The culture of Speed: The Coming of Immediacy. London, Thousand Oaks, New Delhi \& Singapore: Sage.

Turkle, Sh. (2008) Alway on, always on you: thetered self, pp. 121-138. In: J. E. Katz (ed.) Handbook of Mobile Communication Studies. London: The MIT Press.

Virilio, P (2005) The Information Bomb. London: Verso.

Voloshinov, V. N. (1986) Marxism and the Philosophy of Language. Cambridge: Harvard University Press

Wertsch, J. M. (1991) Voices of the Mind. A Sociocultural Approach to Medated Action. Cambridge: Harvard University Press.

Yates, J. \& Orlikowski, W. J. (1992) Genres of Organizational Communication: A Structural Approach to Studying Communication \& Media, The Academy of Management Review, New York, 17(2): 299-326. 


\title{
Svakodnevica u multimedijskom okruženju: medijske prakse mladih i temporalna struktura svijeta života
}

\author{
Antonija Čuvalo
}

\section{SAŽETAK}

U radu autorica istražuje načine na koji mladi koriste svoje multimedijsko okruženje u kontekstu svakodnevnog života. U fokusu rada su pojam vremena i svakodnevni temporaliteti kako su (re)producirani u svakodnevnim interakcijama s različitim medijskim i komunikacijskim tehnologijama.. Autorica se oslanja na concept 'svakodnevice' (dailiness) (Scannell, 1996) koji proširuje i primjenjuje na multimedijsko okruženje kombinirajući fenomenološki pristup s konceptualizacijom vremena u okviru teorije domestikacije (Silverstone, 1993a, 1994). Primjenom kvalitativne interpretativne analize komunikacijskih dnevnika i autobiografskih refleksija studenata identificirano je šest temporalnih žanrova medijskih upotreba: usporavanje, upravljanje tokovima, vremenski stroj, orijentacija prema javnim tokovima, prepuštanje tokovima i orijentacija prema personaliziranim tokovima. Identificirani žanrovi pokazuju kako korisnici u svojim svakodnevnim interakcijama s komunikacijskim medijima pregovaraju, suprotstavljaju se, potrvrđuju ili pokušavaju upravljati dominantnom temporalnom orijentacijom u društvima kasne modernosti.

Ključne riječi: novo medijsko okruženje, temporalni žanrovi medijskih upotreba, društvene prakse, svijet života, medijatizirano društvo 